
\title{
$\begin{array}{ll}\text { Research Square } & \begin{array}{l}\text { Preprints are preliminary reports that have not undergone peer review. } \\ \text { They should not be considered conclusive, used to inform clinical practice, } \\ \text { or referenced by the media as validated information. }\end{array}\end{array}$ \\ Formation Mechanism and Anatomical Structure of the Knee Roots of Taxodium Ascendens
}

\section{Zhuangzhuang Qian}

Co-Innovation Center for Sustainable Forestry in Southern China, College of Forestry, Nanjing Forestry University, Nanjing 210037, PR China

\section{Lin Wu}

Co-Innovation Center for Sustainable Forestry in Southern China, College of Forestry, Nanjing Forestry University, Nanjing 210037, PR China

Luozhong Tang ( $\square$ luozhongtang@njfu.edu.cn )

Nanjing Forestry University

\section{Research Article}

Keywords: anatomic structure, ethylene, flooding, formation mechanism, knee root, Taxodium ascendens

Posted Date: May 27th, 2021

DOI: https://doi.org/10.21203/rs.3.rs-533919/v1

License: (1) (1) This work is licensed under a Creative Commons Attribution 4.0 International License. Read Full License 


\section{Formation mechanism and anatomical structure of}

2

3

4

6

7

8

9

10

11

12

13

14

15

16

17

18

19

Fax: 86-025-85428883

\section{(1)}

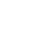

(1)

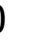

Corresponding author:
Dr. Luozhong Tang

Tel: $86-025-85427325$

\section{Zhuangzhuang Qian; Lin Wu; Luozhong Tang"}

Co-Innovation Center for Sustainable Forestry in Southern China, College of Forestry, Nanjing

Forestry University, Nanjing 210037, PR China

Co-Innovation Center for Sustainable Forestry in Southern China, College of Forestry, Nanjing Forestry University, Nanjing 210037, PR China

159 Longpan Road, Nanjing 210037, PR China

17 E-mail address: luozhongtang@ njfu.edu.cn 


\section{Abstract}

23 Aims: Flooding seriously limits the growth and distribution of plants. Taxodium ascendens is a typical

24 tree species with high flood tolerance, and it can generate knee roots in the wetlands. This study was

25 conducted to understand the formation mechanism of the knee roots.

26 Methods: The number and size of knee roots and soil flooding conditions were investigated in this

27 study. Furthermore, physiology, biochemical responses, and the anatomical structure of knee roots and

28 underground roots were measured at different developmental stages.

29 Results: The results show that the formation of knee roots was significantly affected by the soil water

30 table $(P<0.05)$. Moreover, knee root formation was affected by ethylene and indole-3-acetic acid

31 (IAA) concentrations in the roots. The 1-aminocyclopropane-1-carboxylic acid (ACC) content and

32 ACC synthase activity were significantly lower in the knee roots than in the underground roots. The

33 ethylene release rate was significantly higher in the knee roots than in the underground roots $(P<$

34 0.05), and IAA content first increased and then decreased with knee root development. The cells of the

35 periderm at the apex of the knee roots were dead and had a large number of intercellular spaces, which

36 was beneficial for the growth of T. ascendens.

37 Conclusions: Seasonal flooding induced the production of endogenous hormones, resulting in the

38 formation of knee roots, which improved root respiration and ventilation. The results obtained can

39 gain a basis for the formation mechanism of knee roots and provide scientific evidence for the afforestation and management under wetland conditions. 
41 Keywords: anatomic structure; ethylene; flooding; formation mechanism; knee root; Taxodium

42 ascendens

43 


\section{Introduction}

$$
\text { Nowadays, flood damage is receiving a lot of attention, as flooding and waterlogging phenomena }
$$

tend to be closely associated with global climate changes (Hirabayashi et al. 2013, Zhou et al. 2020).

Flooding and submergence are major abiotic stresses that determine species distribution, growth, and yield (Sairam et al. 2008, Herzog et al. 2016). In China, about $6.6 \times 10^{5} \mathrm{~km}^{2}$ land is waterlogged, accounting for $6.6 \%$ of the total land area; in 2020, 16 provinces and 11.22 million people were adversely affected by floods. Uneven precipitation and poor drainage result in frequent waterlogging, which can seriously constrain crop growth and productivity (Kuai et al. 2015, Liu et al. 2019, Xiong et al. 2019). Therefore, selection of a suitable farmland shelter forest is important. Flooding stress restricts the diffusion of oxygen in plant tissues, which seriously affects plant growth (Voesenek and Baileyserres 2013). Flood-tolerant plant species have a series of adaptive mechanisms, such as morphological changes and physiological and biochemical reactions, that can protect the plants from flooding stress (Khan et al. 2020). The responses of the roots to flood environments reflect the adaptability of a tree to waterlogging (Blom and Voesenek 1996). For example, the structures of some Chenopodiaceae roots change to the herring-bone shape to consume less oxygen and avoid being damaged by toxins (Bouma et al. 2001). The red mangrove (Rhizophora mangle) in coastal intertidal zones has a conspicuous system of stilt-like roots that grow from the main stem and resemble flying buttresses with developed leaf aerenchyma for gas exchange and prevention of oxygen loss during flooding stress (Lance and Alison 2010, Mendez-Alonzo et al. 2015). Avicennia marina can develop finger-like pneumatophores to obtain oxygen for its underground root system and sustain hypoxic 
64

65

66

67

68

69

is widely cultivated in farmland shelter forests and as a roadside tree (Tang et al. 2008, Du et al. 2010).

71

Sakio and Yamamoto (2002) have reported that only some specific flood-tolerant plant species like $T$.

72

73

74

75

76

77 hypothesized the interaction between ethylene and indole-3-acetic acid (IAA) in knee root production. ascendens, Taxodium distichum, and Glyptostrobus pensilis develop knee roots.

Although various studies have reported the effects of waterlogging on the metabolic and physiochemical characteristics of different trees, most of the studies were conducted in greenhouses and focused on tree seedlings (Conner et al. 1997, Andrson and Pezeshki 1999, Li et al. 2010, Wang et al. 2016) and few studies were performed using adult trees under field conditions. Therefore, the formation mechanism of aerial and knee roots, which are generated in only adult trees, have not yet been elucidated. Moreover, the adaptation mechanism of roots that respond to waterlogging stress is unclear. Yamamoto (1992) reported that the depth of flooding affects the formation of knee roots and

81 Ethylene plays an important role in promoting plant growth and seed germination and enhancing anoxia resistance. Especially, ethylene, as an internal gaseous signal, is used by plants to sense shifts 
83 from aerial to aquatic environments and induce changes in plant morphology and anatomy (Visser and

84 Voesenek 2004, Jackson 2007). Sundberg et al. (1991) indicated that endogenous IAA is a key

85 regulator of the development of the secondary vascular tube, and it has significant effects on cambial

86 activity and development. 1-Aminocyclopropane-1-carboxylic acid (ACC) synthetase and ACC

87 oxidase are essential enzymes that participate in the conversion of ACC to ethylene (Dong et al. 1992,

88 Vall-llaura et al. 2020).

89 Therefore, we hypothesized that the formation of knee roots was associated with the flooding

90 condition, and induced by endogenous hormones. In this study, the water table, ethylene and relative

91 enzymes, IAA content, and anatomical structure of knee roots and conventional underground roots of

$92 T$. ascendens were evaluated. The objective of this study was to compare the differences in

93 endogenous hormones between the knee roots developed from underground roots and conventional

94 underground roots, to understand the adaptation mechanism of T. ascendens under flooding conditions

95 and form a basis for afforestation management under wetland conditions.

96 Materials and methods

97 Research site

The study was performed in a 28-year-old Taxodium ascendens forest plantation (approximately

99500 hectares). The plantation was cultivated in a wetland at the Zhaoguan Forest Farm (N32 $31^{\prime} 41^{\prime \prime}$

100 and E119³0'35"), Jiangdu County, Jiangsu Province, China, and the plant spacing was $1.5 \mathrm{~m} \times 4 \mathrm{~m}$. 
101 The average tree diameter at breast height (DBH) and tree height were $25.75 \mathrm{~cm}$ and $14.33 \mathrm{~m}$,

102 respectively. The soil type was paddy soil with poor air permeability.

103 Three experimental sites were chosen on the basis of the soil water table: high water table site

104 (the flooding period was more than 3 months from June to September, maximum submergence depth

105 was about $0.8 \mathrm{~m}$, and annual average water table was more than $-0.6 \mathrm{~m}$ ), middle water table site (the

106 flooding period was 1 to 2 months from July to August, maximum submergence depth was about 0.2

$107 \mathrm{~m}$, and annual average water table was from $-0.6 \mathrm{~m}$ to $-1.2 \mathrm{~m}$ ), and low water table site (no flooding

108 status, and the annual average water table was less than $-1.2 \mathrm{~m}$ ). A total of 21 plots (7 sampling plots

109 at each water-table site) were established, and each plot was $96 \mathrm{~m}^{2}(8 \times 12 \mathrm{~m})$.

\section{Analysis of the soil water table and knee root number and size}

111 The soil water table at each site was measured every mid-month from Oct 2011 to Oct 2016. The

112 tree height, DBH, and number and size of knee roots were measured in October 2016.

114 table. The pipes were drilled with $4 \mathrm{~mm}$ diameter holes (the spacing between each hole was $5 \mathrm{~cm}$ ) and

115 vertically buried in the soil at each site. The height of the knee roots (the height from the ground to the

116 apex of the knee roots) and average diameter at half the height of the knee roots were also measured.

117 Because the surface of the knee roots was irregular, we carefully wrapped the knee roots exposed

118 above the ground with tape (width, $1.62 \mathrm{~cm}$ ). The surface area was calculated according to the length

119 and width of the tape (with no overlap in the wrapping process). The survey of underground roots with 
$121 \mathrm{~m}$ from $T$. ascendens. The underground roots (depth, $0-50 \mathrm{~cm}$ ) were excavated, cleaned, dried, and

122 weighed.

\section{Sampling of knee roots and assay of physiological indicators}

124 In October 2016, the middle water table sites were chosen to investigate the development stages

125 of the knee roots. The knee roots were divided into three stages on the basis of size and age: young-

126 aged stage (Fig. 1A), middle-aged stage (Fig. 1B), and old-aged stage (Fig. 1C). The knee roots at the

127 young-aged stage were less than $5 \mathrm{~cm}$ in height and less than 5 years of age. The knee roots at the

128 middle-aged stage were 5 to $10 \mathrm{~cm}$ in height and 5 to 10 years of age. The knee roots at the old-aged

129 stage were more than $10 \mathrm{~cm}$ in height and more than 10 years of age. The age of the knee roots was

130 determined using the annual rings in the transverse section. The knee root samples were divided into

131 two parts: the swollen part (upside) and non-swollen part (underside). Underground roots

132 approximately $10 \mathrm{~mm}$ in diameter were collected as the control. The root tissues were randomly

133 selected for physiological assay.

\section{Ethylene release rate of the roots}

135 Fresh root cambium tissues $(0.6 \mathrm{~g})$ were sealed in a closed bottle and incubated for $4 \mathrm{~h}$ at $30{ }^{\circ} \mathrm{C}$.

136 Then, gas samples $(0.5 \mathrm{~mL})$ were collected from the incubator to determine the ethylene concentration

137 by using a gas chromatograph equipped with a flame ionization detector (FID) and electron capture 

used to calculate the ethylene concentration of the samples.

\section{ACC content}

141 The ACC content was determined according to Hoffman et al. (1983). The root cambium tissue samples were cut into small pieces and mixed completely. Then, the samples $(1.0 \mathrm{~g})$ were

143 homogenized in $8 \mathrm{~mL}$ of ethanol $(95 \%)$ and centrifuged $(8000 \times g)$ at $4{ }^{\circ} \mathrm{C}$ for $15 \mathrm{~min}$; the

144 supernatant was transferred to a plastic bottle, $6 \mathrm{~mL}$ of ethanol $(80 \%)$ was added to the residue and

145 shaken for $30 \mathrm{~min}$, the supernatant after centrifugation was transferred to the previous bottle, and the

146 bottle was dried in a water bath at $40{ }^{\circ} \mathrm{C}$. The dried residue was dissolved with $5 \mathrm{~mL}$ of distilled water

147 and then centrifuged $(8000 \times g)$ at $4{ }^{\circ} \mathrm{C}$ for $10 \mathrm{~min}$. The supernatant was used as the ACC fluid; $1 \mathrm{~mL}$

148 of the fluid and $40 \mu \mathrm{L}$ of $\mathrm{HgCl}_{2}\left(25 \mathrm{mmol} \cdot \mathrm{L}^{-1}\right)$ were added into test tubes $(20 \mathrm{~mL})$ closed with rubber

149 stoppers. Then, $1 \mathrm{~mL}$ of $\mathrm{NaOCI}-\mathrm{NaOH}(\mathrm{v}: \mathrm{v}=2: 1)$ was injected into the test tubes with a syringe. The

150 tubes were shaken for $10 \mathrm{~min}$, and gas samples $(0.5 \mathrm{~mL})$ were collected from the tubes to determine

151 the ethylene concentration via gas chromatography. The ACC concentration of fresh root samples was

152 calculated using the following formula:

$$
\text { ACC content }\left(\mathrm{nmol} \cdot \mathrm{g}^{-1} \mathrm{FW}\right)=\frac{C \times V_{L} \times V}{R \times V_{1} \times V_{2} \times W \times 22.4}
$$

154 where $\mathrm{C}$ is the ethylene concentration measured using gas chromatography $\left(\mathrm{nL} \cdot \mathrm{L}^{-1}\right) ; \mathrm{V}_{\mathrm{L}}$ is the volume

155 of sample bottles without solution $(\mathrm{mL}) ; \mathrm{V}$ is the volume of the extracting solution $(\mathrm{mL})$; $\mathrm{R}$ is the

156 transfer coefficient from ACC to ethylene; $\mathrm{V}_{1}$ is the volume of the extracting solution used for 
158 of the root sample $(\mathrm{g})$; and 22.4 is 1 molar gas constant under normal atmospheric conditions $\left(\mathrm{L} \cdot \mathrm{mol}^{-1}\right)$.

\section{ACC synthase activity} quartz sand at $4{ }^{\circ} \mathrm{C}$ and centrifuged at $10000 \times g$. for $20 \mathrm{~min}$. The extraction buffer solution contained $400 \mathrm{mmol} \cdot \mathrm{L}^{-1}$ potassium phosphate buffer solution $(\mathrm{pH} 8.5), 1 \mathrm{mmol} \cdot \mathrm{L}^{-1}$ ethylene diamine tetraacetic acid, $0.5 \%$ (v:v) $\beta$-mercaptoethanol, and $10 \mu \mathrm{mol} \cdot \mathrm{L}^{-1}$ pyridoxal phosphate (PLP). The supernatant was

170 test tubes were shaken for $10 \mathrm{~min}$, and $0.5 \mathrm{~mL}$ gas sample was collected to determine the ethylene

171 content by using gas chromatography.

\section{ACC oxidase activity}

173 The ACC oxidase activity was determined according to Dong et al. (1992); $0.5 \mathrm{~g}$ of root cambium

174 tissues were ground in a mortar with the extraction buffer $(2 \mathrm{~mL})$ and a small amount of quartz sand at

$1754{ }^{\circ} \mathrm{C}$ and centrifuged at $12000 \times \mathrm{g}$. for $10 \mathrm{~min}$. The extraction buffer solution contained $100 \mathrm{mmol} \cdot \mathrm{L}^{-1}$ 
176 Tris- $\mathrm{HCl}(\mathrm{pH} 7.5), 10 \%(\mathrm{v}: \mathrm{v})$ glycerin, $30 \mathrm{mmol} \cdot \mathrm{L}^{-1}$ sodium ascorbate, $5 \%$ (v:v) polyvinylpyrrolidone,

$1770.1 \mathrm{mmol} \cdot \mathrm{L}^{-1} \mathrm{FeSO}_{4}$, and $5 \mathrm{mmol} \cdot \mathrm{L}^{-1} \mathrm{DTT}$. The supernatant was used to determine ACC oxidase

178 activity; $0.2 \mathrm{~mL}$ of the enzyme extract and $1.8 \mathrm{~mL}$ of the buffer solution (containing $100 \mathrm{mmol} \cdot \mathrm{L}^{-1}$

179 Tris- $\mathrm{HCl}(\mathrm{pH} 7.5), 10 \%(\mathrm{v}: \mathrm{v})$ glycerin, $30 \mathrm{mmol} \cdot \mathrm{L}^{-1}$ sodium ascorbate, $30 \mathrm{mmol} \cdot \mathrm{L}^{-1} \mathrm{NaHCO}_{3}, 1.0$

$180 \mathrm{mmol} \cdot \mathrm{L}^{-1} \mathrm{ACC}$, and $\left.0.1 \mathrm{mmol} \cdot \mathrm{L}^{-1} \mathrm{FeSO}_{4}\right)$ were added to test tubes $(20 \mathrm{~mL})$ closed with rubber

181 stoppers and incubated at $35{ }^{\circ} \mathrm{C}$ for $20 \mathrm{~min}$. Then, $0.5 \mathrm{~mL}$ gas sample was collected to determine the

182 ethylene content by using gas chromatography.

\section{IAA content}

184 The IAA content was determined according to Chen and Zhao (2008), and Yuan et al. (2008).

185 First, $1 \mathrm{~g}$ of root cambium tissues were homogenized in liquid nitrogen and extracted in cold $80 \%$

186 methanol with butylated hydroxytoluene $\left(1 \mathrm{mmol} \cdot \mathrm{L}^{-1}\right)$ overnight at $4{ }^{\circ} \mathrm{C}$, and centrifuged for $10000 \times$

$187 g$-at the same temperature for $15 \mathrm{~min}$. The supernatant was collected and passed through a C18 Sep-

188 Pak Cartridge (Waters Corp., Milford, USA). The efflux was collected and dried in a rotary evaporator

189 (RE-2000A, China). The residue was collected in $0.8 \mathrm{ml}$ mobile phase (consisting of 23\% (v:v)

190 methanol and 23\% (v:v) acetonitrile in double distilled water supplemented with $0.1 \%$ (v/v)

191 phosphoric acid), filtered through a $0.25 \mathrm{~mm}$ filter and submitted for HPLC analysis. The IAA content

192 was determined using the external standard method with a Waters 2695 Alliance HPLC (Waters

193 Corp.). A Symmery C18 column (Waters Corp.) $(4.6 \times 250 \mathrm{~mm}, 5 \mu \mathrm{m})$ and a detection wavelength of 

$254 \mathrm{~nm}$ were used. A sample $(50 \mu \mathrm{l})$ was automatically injected at a flow rate of $0.5 \mathrm{ml} \mathrm{min}^{-1}$.

195 Quantification was made by comparing the peak areas with the known amounts of IAA (Sigma).

\section{Anatomical analysis of knee roots and underground roots}

197 Three samples containing bark and currently produced xylem from the apex of knee roots at the

198 middle-aged stage and mid-sized underground roots were obtained (Fig. 2). Small pieces $(10 \times 10 \times$

$19910 \mathrm{~mm}$ ) of these root materials were fixed in FAA solution (formalin:acetic acid:ethanol:water,

200 5:5:60:30, v:v) for $24 \mathrm{~h}$, rinsed in water, dehydrated in ethanol, and sealed in a paraffin block. The

201 samples were transversely sectioned $(10 \mu \mathrm{m})$ with a slide microtome (Leica RM2125RT, Germany),

202 dewaxed, stained with safranin-fast green solution, and oven-dried at $40{ }^{\circ} \mathrm{C}$. The anatomical structure

203 of the samples was observed under a light microscope (Olympus, Japan), and the pictures were taken

204 and processed using an image analysis software (DT2000, China).

\section{Statistical analysis}

The data were calculated and plotted using Microsoft Office Excel 2016, and all data were

207 subjected to analysis of variance by using IBM SPSS Statistics 19.0. To determine the effects of the

208 knee roots on the growth of $T$. ascendens, correlation analysis was performed using IBM SPSS

209 Statistics 19.0. The data were presented as mean \pm standard deviation $(\mathrm{M} \pm \mathrm{SD})$ values, and 210 differences in the data were evaluated using Duncan's test at a significance level of 0.05.

\section{Results}


table

214

The tree height, DBH, underground roots, and knee roots of $T$. ascendens were investigated, and the results showed that the formation and distribution of knee roots were significantly affected by the that in the high water table and low water table, respectively. The height and diameter of the knee roots were also observed to be higher in the middle water table site (Table 1); thus, the middle water table significantly increased knee root formation and growth $(P<0.05)$.

Effects of the knee roots on the growth of $T$. ascendens

227 underground roots was significantly correlated with the mean height and surface area of knee roots.

\section{Biochemical analysis of the roots}

\section{ACC content and ACC synthase and ACC oxidase enzyme activities}


231 differences $(P>0.05)$ : KY $>\mathrm{KM}>\mathrm{KO}$ (Fig. 4A). However, the ACC content was significantly lower

232 in the knee roots than in the underground roots $(P<0.05)$. The ACC synthase activity showed the

233 same trend as ACC content and was not significantly different among the development stages of the

234 knee roots (Fig. 4B), and the ACC synthase activity was significantly lower in the knee roots than in

235 the underground roots $(P<0.05)$. The ACC oxidase activity in the knee roots at different development

236 stages was in the order of $\mathrm{KY}>\mathrm{KM}>\mathrm{KO}$, and $\mathrm{ACC}$ oxidase reduced with the growth of knee roots

237 (Fig. 4C). The ACC oxidase activity was significantly higher in the knee roots than in the underground

238 roots, except in KO (Fig. 4C; $P<0.05$ ).

239 Endogenous hormone release rates

240 Different ethylene release rates were observed in the underground roots and knee roots (Fig. 5A).

241 The ethylene release rate at different stages was significantly higher in the knee roots than in the

242 underground roots $(P<0.05)$. In addition, significant differences were observed among the different

243 development stages of the knee roots $(P<0.05)$. The maximum ethylene release rate from the knee

244 roots was observed in $\mathrm{KO}$, and the minimum, in $\mathrm{KM}$.

245 The IAA content was in the order of UR $>\mathrm{KM}>\mathrm{KO}>\mathrm{KY}$ (Fig. 5B), with no statistically

246 significant differences between UR and KM $(P>0.05)$ and $\mathrm{KO}$ and $\mathrm{KY}(P>0.05)$.

\section{Anatomical structure of the knee roots and underground roots}


249 periderm and phloem, and some parts of the periderm had branches (Fig. 6). The periderm was

250 composed of many layers of cork cells, and the cork layer, cork-forming layer, and inner cork layer

251 were closely overlapped. The phloem, isolated from the periderm on the apex side of the knee roots,

252 was dead, the cells were broken, and the arrangement of cells was loose and porous. The phloem

253 parenchyma cells were close to the cambium and rectangular. The cell wall of the phloem fiber was

254 thickened and showed an increase in lignification. The phloem ray expanded obviously, and the

255 arrangement was loose. The knee roots were mainly composed of the secondary xylem; in the cross-

256 section, xylem tracheids were arranged in order; the early tracheids were rectangular, square, or

257 polygonal; the late tracheids were obviously smaller than the early tracheids; and the cell wall was

258 thicker. The rhytidome layers of the underground roots were lesser than those of the knee roots (1-2

259 layers). The width of the phloem was smaller than that of the knee roots; the xylem tracheids were

260 arranged in order, and the shape was similar to that of the knee roots.

\section{Discussion}

In plants, flood tolerance is related to shifts in anatomical and morphological characteristics

(Blom and Voesenek 1996, Hua et al. 2017). Under flooding conditions, the formation of knee roots is a morphological adaptation of T. ascendens to environmental stress (Fig. 7). Taxodium ascendens with 
267 more suitable for the formation and growth of knee roots, which is consistent with the findings of

268 Tang et al. (2008) who reported that T. ascendens formed aerating roots in the high water table and

269 knee roots in the middle water table.

Ethylene production plays an important role in modifying the plant response to flooding stress

271 (Zhou et al. 2020). Ethylene induces the genes of enzymes associated with aerenchyma formation

272 (Drew et al. 1979, Brailsford et al. 1993, Sairam et al. 2008). Ethylene synthesis includes two

273 important processes: catalysis of $S$-adenosylmethionine (SAM) to ACC by ACC synthase and catalysis

274 of ACC to ethylene by ACC oxidase. ACC synthesis does not require oxygen; in fact, ACC synthase

275 activity is stimulated in roots under flood conditions (Cohen and Kende 1987, Dong et al. 1992, Zhou

276 et al. 2001; Williams and Golden 2002). In our study, the underground roots of T. ascendens were

277 exposed to anoxic conditions for a long time; expression of the ACC synthetase gene was stimulated

278 by anaerobic stress (Van der Straeten et al. 2001, Rieu et al. 2005), which increased ACC synthetase

279 activity in the underground roots. However, the knee roots were exposed to air in October (sampling

280 time); thus, the activity of ACC synthetase was significantly lower in the knee roots than in the

281 underground roots. The conversion of ACC to ethylene has an obligate requirement for oxygen, and

282 ACC oxidase can also be induced by anoxic stress (Vriezen et al. 1999, Bailey-Serres and Voesenek

283 2008, Buttò et al. 2020). Thus, our results suggest that the oxygen status was improved by the

284 formation and development of knee roots, ACC oxidase activity decreased with the development of

285 knee roots, knee roots at the young-aged stage showed the highest ACC oxidase activity, knee roots at 
286 the old-aged stage may be less affected by flooding stress, and showed the lowest ACC oxidase

287 activity. When the underground roots of T. ascendens were exposed to flooding in the growing season,

288 the activity of ACC synthase was enhanced by anaerobic stress, which led to the accumulation of ACC.

289 When the water table receded, the upper surface of the roots distributed in the shallow soil received

290 oxygen, and the ACC was transported to better-aerated tissues. This resulted in ethylene synthesis by

291 ACC oxidase; ethylene promoted the uneven growth of morphologically upper and lower roots,

292 leading to the formation of knee roots. Thus, the knee roots had significantly higher ethylene content

293 than the underground roots (Fig. 5A), and the highest ethylene content was observed in the old-aged

294 stage of the knee roots. This is consistent with the results of Pesquet and Tuominen (2011), who

295 reported that the ethylene content was maximum before cell death and lignification. The knee roots

296 formed easily when the tree was exposed to anoxic conditions (reduction state) and aerobic conditions

297 (oxidation state) alternately. Thus, our results suggest that the high water table (the underground roots

298 experienced flooding from June to September, and the soil was in the reduction state during the

299 growing season) and low water table (no flooding throughout the year, and the soil was in oxidation

300 state) are not suitable for the formation of knee roots; only the middle water table (flooding period was

3011 to 2 months from July to August, and the annual average water table was from $-0.6 \mathrm{~m}$ to $-1.2 \mathrm{~m}$ ) is

302 suitable for the formation of knee roots. Moreover, ACC and some related enzymes were found in the

303 knee root tissues, suggesting that the formation and development of $T$. ascendens knee roots are

304 related to ethylene production and accumulation. 
and Voesenek 2004, Kitomiy et al. 2008). IAA also plays an important role in the development and

307 activities of the cambium (Uggla et al. 1998, Bhalerao and Fischer 2014). Our study suggests that,

308 with the development of the knee roots, the IAA content first increased and then decreased; IAA

309 content was lower in the knee roots at the young-aged and old-aged stages and higher in those at the

310 middle-aged stage. High IAA content is beneficial for cambium cell enlargement, expansion, and

311 division (Bhalerao and Fischer 2016), whereas low IAA content is beneficial for secondary cell-wall

312 deposition and lignification (Fajstavr et al. 2018). Our results were similar to the conclusion of Cui et

313 al. (1999, 2000), who reported that endogenous IAA concentration in the cambium of Broussonetia

314 papyrifera increased obviously when the cambium formed the immature phloem and xylem and

315 decreased when the immature vascular cells differentiated towards maturation; this indicates IAA

316 concentrations are different in the division stage of cambium cells and differentiation stage of

317 cambium derivative cells. al. 2000). In our study, the cells of the periderm at the apex of the knee roots were dead, arranged loosely, and had a large number of intercellular spaces, which is conducive to gas exchange between

322 the knee roots and air. Because the knee roots were exposed to air to resist the adverse effects of 323 external environmental factors, the periderm of the knee roots was obviously thicker than that of the 
324 underground roots. Plant stems can form irregular wide rays composed of abnormally large ray cells

325 after the application of ethephon (Pallardy 2011). Because the knee roots were stimulated by ethylene,

326 phloem rays at the apex of the knee roots expanded obviously when compared with the underground

327 roots. Thus, the flooding resistance of $T$. ascendens is related to the formation of knee roots and

328 enhancement of air permeability. Although this study showed that ACC, ethylene, and IAA affected

329 the formation of knee roots, the underlying molecular mechanism is still unclear. We recommend the

330 transcription factors and gene expression of $T$. ascendens roots should be explored to further

331 understand the mechanism of flooding resistance.

\section{Conclusions}

Our results suggest that the formation and distribution of knee roots are significantly affected by

334 the water table. The middle water table significantly enhanced the formation and distribution of knee

335 roots in T. ascendens. Furthermore, the knee roots were beneficial for the growth of T. ascendens, and

336 the height and the DBH of T. ascendens were positively correlated with the number and size of knee

337 roots. The ACC content and ACC synthase activities in the knee roots at different development stages

338 did not show any significant differences, whereas they were significantly lower in the knee roots than

339 in the underground roots. The ACC oxidase activities in the knee roots decreased as the knee roots

340 developed. Ethylene and IAA affected the formation of knee roots. The ethylene release rate was

341 significantly higher in the knee roots than in the underground roots, and the IAA content first

342 increased and then decreased with the development of the knee roots. The anatomical structure of the 
343 knee roots showed that cells of the periderm at the apex of the knee roots were dead, arranged loosely,

344 and had a large number of intercellular spaces that improved internal gas diffusion. In conclusion,

345 seasonal flooding induced the production of endogenous hormones, resulting in the formation of knee

346 root, which improved root respiration and ventilation, thus improving the flooding tolerance of $T$.

347 ascendens.

348 Conflicts of Interest

349 The authors declare no conflict of interest.

350 Acknowledgement

351 This study was funded by the National Natural Science Foundation of China (No. 31170566) and

352 the Priority Academic Program Development of Jiangsu Higher Education Institutions (PAPD).

353 References

354 Andrson PH, Pezeshki SR (1999) The effects of intermittent flooding on seedlings of three forest

$355 \quad$ species. Photosynthetica 37(4): 543-552.

356 Bailey-Serres J, Voesenek LACJ (2008) Flooding stress: Acclimations and genetic diversity. Annu

$357 \quad$ Rev Plant Biol 59: 313-339.

358 Bhalerao RP, Fischer U (2014) Auxin gradients across wood—instructive or incidental? Physiol Plant

$359 \quad 151: 43-51$

360 Bhalerao RP, Fischer U (2016) Environmental and hormonal control of cambial stem cell dynamics. J 
Blom CW, Voesenek LA (1996) Flooding: the survival strategies of plants. Trends Ecol Evol 11(7):

363

364

365

366

367

368

369

370

371

372

373

374

375

376

377

378

379

380

290-295.

Bouma TJ, Nielsen KL, Van Hal J, Koutstaal B (2001) Root system topology and diameter distribution of species from habitats differing in inundation frequency. Funct Ecol 15(3): 360-369.

Brailsford, RW, Voesenek LACJ, Blom CWPM, Smith AR, Hall MA, Jackson MB (1993) Enhanced ethylene production by primary roots of Zea mays L. in response to sub-ambient partial pressure of oxygen. Plant Cell Environ 16: 1071-1080.

Buttò V, Deslauriers A, Rossi S, Rozenberg P, Shishov V, Morin H (2020) The role of plant hormones in tree-ring formation. Trees 34(2) doi:10.1007/s00468-019-01940-4

Chen D, Zhao J (2008) Free IAA in stigmas and styles during pollen germination and pollen tube growth of Nicotiana tabacum. Physiol Plantarum 134(1): 202-215.

Cohen E, Kende H (1987) In vivo 1-aminocyclopropane-1- carboxylate synthase activity in internodes of deep water rice: Enhancement by submergence and low oxygen levels. Plant Physiol 84: 282286.

Conner WH, McLeod KW, McCarron JK (1997) Flooding and salinity effects on growth and survival of four common forested wetland species. Wetl Ecol Manag 5(2): 99-109.

Cui K, Wang X, Duan J, Wang SY (1999) Change of endogenous IAA during cambial activity and IAA binding protein in cambial cells in Broussonetia papyrifera. Acta Botanica Sinica 41(10): 1082-1085. (in Chinese) 
381 Cui K, Wang X, Duan J (2000) Change in the concentration and tissue - localization of endogenous

382 IAA during the regeneration after girdling in Broussonetia papyrifera (L.) Vent. Acta

383 Scientiarum Naturalium Universitatis Pekinensis 36(4): 495-502. (in Chinese)

384 Dong JG, Fernández-Maculet JC, Yang SF (1992) Purification and characterization of 1-

385 aminocyclopropane-1-carboxylate oxidase from apple fruit. P Natl Acad Sci USA 89(20): 9789-

3869793.

387 Drew MC, He CJ, Morgan PW (2000) Programmed cell death and aerenchyma formation in roots.

388 Trends Plant Sci 5: 123-127.

389 Drew MC, Jackson MB, Giffard S (1979) Ethylene-promoted adventitious rooting and development of

390 cortical air spaces (aerenchyma) in roots may adaptive responses to flooding in Zea mays L.

$391 \quad$ Planta 147: 83-88.

392 Du Q, Zhong QC, Wang KY (2010) Root effect of three vegetation types on shoreline stabilization

393 of Chongming Island, Shanghai. Pedosphere 20(6): 692-701.

394 Fajstavr M, Paschová Z, Giagli K, Vavrčík H, Gryc V, Urban J (2018) Auxin (IAA) and soluble 395 carbohydrate seasonal dynamics monitored during xylogenesis and phloemogenesis in Scots pine. iForest 11: 553-562.

397 He CJ, Finlayson SA, Drew MC, Jordan WR, Morgan PW (1996) Ethylene biosynthesis during aerenchyma formation in roots of maize subjected to mechanical impedance and hypoxia. Plant Physiol 112: 1679-1685. 
400

401

402

403

404

405

406

407

408

409

410

411

412

413

414

415

416

417

418

Herzog M, Striker GG, Colmer TD, Pedersen O (2016) Mechanisms of waterlogging tolerance in wheat - a review of root and shoot physiology. Plant Cell Environ 39(5): 1068-1086.

Hirabayashi Y, Mahendran R, Koirala S, Konoshima L, Yamazaki D, Watanabe S, Kanae S (2013) Global flood risk under climate change. Nat Clim Change 3(9): 816-821.

Hoffman NE, Liu Y, Yang SF (1983) Changes in 1- (malonylamino) cyclopropane-1-carboxylic acid content in wilted wheat leaves in relation to their ethylene production rates and 1aminocyclopropane-1-carboxylic acid content. Planta 157(6): 518-523.

Hua J, Han L, Wang Z, Gu C, Yin Y (2017) Morpho-anatomical and photosynthetic responses of Taxodium hybrid 'Zhongshanshan' 406 to prolonged flooding. Flora 231: 29-37.

Jackson MB (2007) Ethylene-promoted elongation: an adaptation to submergence stress. Ann BotLondon 101: 229-248.

Khan M, Iqbal R, Trivellini A, Chhillar H, Chopra P, Ferrante A, Khan NA, Ismail AM (2020) The significance and functions of ethylene in flooding stress tolerance in plants. Environ Exp Bot 104188. doi:10.1016/j.envexpbot.2020.104188

Kitomiy Y, Ogawa A, Kitanoh I, Inukai Y (2008) CRLA regulates crown root formation through auxin transport in rice. Plant Root 2: 19-28.

Kuai J, Zhou Z, WangY, Meng Y, Chen B, Zhao W (2015) The effects of short-term waterlogging on the lint yield and yield components of cotton with respect to boll position. Europ J Agronomy 67: $61-74$ 
Lance SE, Alison B (2010) Characterization of cork warts and aerenchyma in leaves of Rhizophova mangle and Rhizophora racemosa. J Torrey Bot Soc 137(1): 30-38. doi:10.2307/40864968 adaptation of Taxodium distichum and Taxodium ascendens seedlings to different soil water regimes. Plant Soil 329: 481-494.

424

Liu D, Liu S, Yi P, Yin H, Xie B, Liu Z (2019) Effects of exogenous hormones on physiological Sciences 47(9): 182-185. (in Chinese)

427

Mehta AM, Jordan RL, Anderson JD, Mattoo AK (1988) Identification of a unique isoform of 1aminocyclopropane -1-carboxylic acid synthase by monoclonal antibody. P Natl Acad Sci USA 85(23): 8810-8814.

Mendez-Alonzo R, Moctezuma C, Ordonez VR, Angeles G, Martinez AJ, Lopez-Portillo J (2015) Root biomechanics in Rhizophora mangle: anatomy, morphology and ecology of mangrove's flying buttresses. Ann Bot-London 115(5): 833-840.

433

Pallardy SG (2011) Physiology of woody plants. Science Press, Beijing. cell cultures. New Phytol 190: 138-149. 
438

439

440

441

442

443

444 Sairam RK, Kumutha D, Ezhilmathi K, Deshmukh PS, Srivastava GC (2008) Physiology and

445

446

447

448

449

450

451

452

453

454

455

456

Purnobasuki H, Purnama PR, Kobayashi K (2017) Morphology of four root types and anatomy of root-root junction in relation gas pathway of Avicennia marina (Forsk) Vierh roots. International Journal of Plant Research 30(2): 100. doi: 10.5958/2229-4473.2017.00143.4

Rieu I, Cristescu SM, Harren FJM, Huibers W, Voesenek LACJ, Mariani C, Vriezen WH (2005) RPACS1, a flooding-induced 1-aminocyclopropane-1-carboxylate synthase gene of Rumex palustris, is involved in rhythmic ethylene production. J Exp Bot 56: 841-849. biochemistry of waterlogging tolerance in plants. Bio Plantarum 52(3): 401-412.

Sakio H, Yamamoto F (2002) Ecology of riparian forests. University of Tokyo Press, Tokyo.

Sena Gomes AR, Kozlowski TT (1980) Effects of flooding on Eucalyptus camaldulensis and Eucalyptus globulus seedlings. Oecologia 46(2): 139-142.

Sundberg B, Little CH, Cui K, Sandberg G (1991) Level of endogenous indole-3-acetic acid in the stem of Pinus sylvestris in relation to the seasonal variation of cambial activity. Plant Cell Environ 14(2): 241-246.

Tang LZ, Huang BL, Haibara K, Toda H (2008) Ecological adaption mechanisms of roots to flooded soil and respiration characteristics of knee roots of Taxodium ascendens. Journal of Plant Ecology 32(6): 1258-1267. (in Chinese)

Uggla C, Mellerowicz EJ, Sundberg B (1998) Indole-3-acetic acid controls cambial growth in Scots pine by positional signaling. Plant Physiol 117(1): 113-121. 
457

458

459

460

461

462

463

464

465

466

467

468

469

470

471

472

473

474 Williams OJ, Golden KD (2002) Purification and characterization of ACC oxidase from Artocarpus

475

Vall-llaura N, Giné-Bordonaba J, Usall J, Larrigaudière C, Teixidó N, Torres R (2020) Ethylene biosynthesis and response factors are differentially modulated during the interaction of peach petals with Monilinia laxa or Monilinia fructicola. Plant Sci 299: 110599. doi:10.1016/j.plantsci.2020.110599

Van der Straeten D, Zhou Z, Prinsen E, Van Onckelen HA, Van Montagu MC (2001) A comparative molecular physiological study of submergence response in lowland and deepwater rice. Plant Physiol 125: 955-968.

Visser EJW, Voesenek LACJ (2004) Acclimation to soil flooding - sensing and signal-transduction. Plant Soil 254: 197-214.

Voesenek LA, Baileyserres J (2013) Flooding tolerance: $\mathrm{O}_{2}$ sensing and survival strategies. Curr Opin Plant Biol 16: 647-653.

Vriezen WH, Hulzink R, Mariani C, Voesenek LACJ (1999) 1-Aminocyclopropane-1-carboxylate oxidase activity limits ethylene biosynthesis in Rumex palustris during submergence. Plant Physiol 121: 189-195.

Wang C, Li C, Hong W, Wei X, Han W (2016) Effects of long-term periodic submergence on photosynthesis and growth of Taxodium distichum and Taxodium ascendens saplings in the hydro-fluctuation zone of the Three Gorges Reservoir of China. Plos One 11(9): e0162867. altilis. Plant Physiol Bioch 40(4): 273-279. 
476 Xiong Q, Cao C, Shen T, Zhong L, He H, Chen X (2019) Comprehensive metabolomic and proteomic

477 analysis in biochemical metabolic pathways of rice spikes under drought and submergence stress.

$478 \quad$ BBA - Proteins Proteom 1867: 237-247.

479 Yamamoto F (1992) Effects of depth of flooding on growth and anatomy of stems and knee roots of

481 Yi YH, Fan DY, Xie ZQ, Chen FQ (2008) The effects of waterlogging on photosynthesis-related ecophysiological processes in the seedlings of Quercus variabilis and Taxodium ascendens. Acta Ecologica Sinica 28(12): 6025-6033.

484

Yuan J, Chen D, Ren YJ, Zhang XL, Zhao J (2008) Characteristic and expression analysis of a metallothionein gene, OsMT2b, down-regulated by cytokinin suggest functions in root development and seed embryo germination of rice (Oryza sativa L.). Plant Physiol 146: 16371650 novel ACC synthase gene in deepwater rice seedlings upon complete submergence. Euphytica 121(2): 137-143.

491 Zhou W, Chen F, Meng Y, Chandrasekaran U, Luo X, Yang W, Shu K (2020) Plant 
495 Table 1 Number and size of knee roots of Taxodium ascendens at different water table sites

\begin{tabular}{cccccc}
\hline Site & Annual Water & Flooding & Knee Root & Knee Root & Knee Root \\
& Table $(\mathrm{m})$ & Period & Density & Height & Diameter \\
& & $\left(\right.$ month year $\left.^{-1}\right)$ & $\left(\right.$ root $\left.\mathrm{m}^{-2}\right)$ & $(\mathrm{cm})$ & $(\mathrm{cm})$ \\
\hline High water & $>-0.6$ & & $0.66 \pm 0.02 \mathrm{~b}$ & $6.65 \pm 1.36 \mathrm{~b}$ & $3.73 \pm 0.12 \mathrm{~b}$ \\
table & & & & & \\
Middle water & & & & & \\
table & -0.6 to -1.2 & 1 to 2 & $1.61 \pm 0.64 \mathrm{a}$ & $7.64 \pm 1.42 \mathrm{a}$ & $4.11 \pm 0.51 \mathrm{a}$ \\
Low water table & $<-1.2$ & 0 & $0.65 \pm 0.02 \mathrm{~b}$ & $6.72 \pm 1.60 \mathrm{~b}$ & $3.70 \pm 0.25 \mathrm{~b}$ \\
\hline
\end{tabular}

496 Data represent mean \pm standard deviation values of seven replication sites.

497 Values followed by the same letter are not significantly different at $P<0.05$, according to Duncan's

498 multiple range tests. The height of the knee roots refers to the height from the ground to the apex of

499 the knee roots. The knee root diameter refers to the average diameter at half the height of the knee

500 roots.

501 
503 Table 2 Correlation coefficient between number and size of knee roots and DBH and tree height of

504 Taxodium ascendens at Zhaoguan Forest Farm

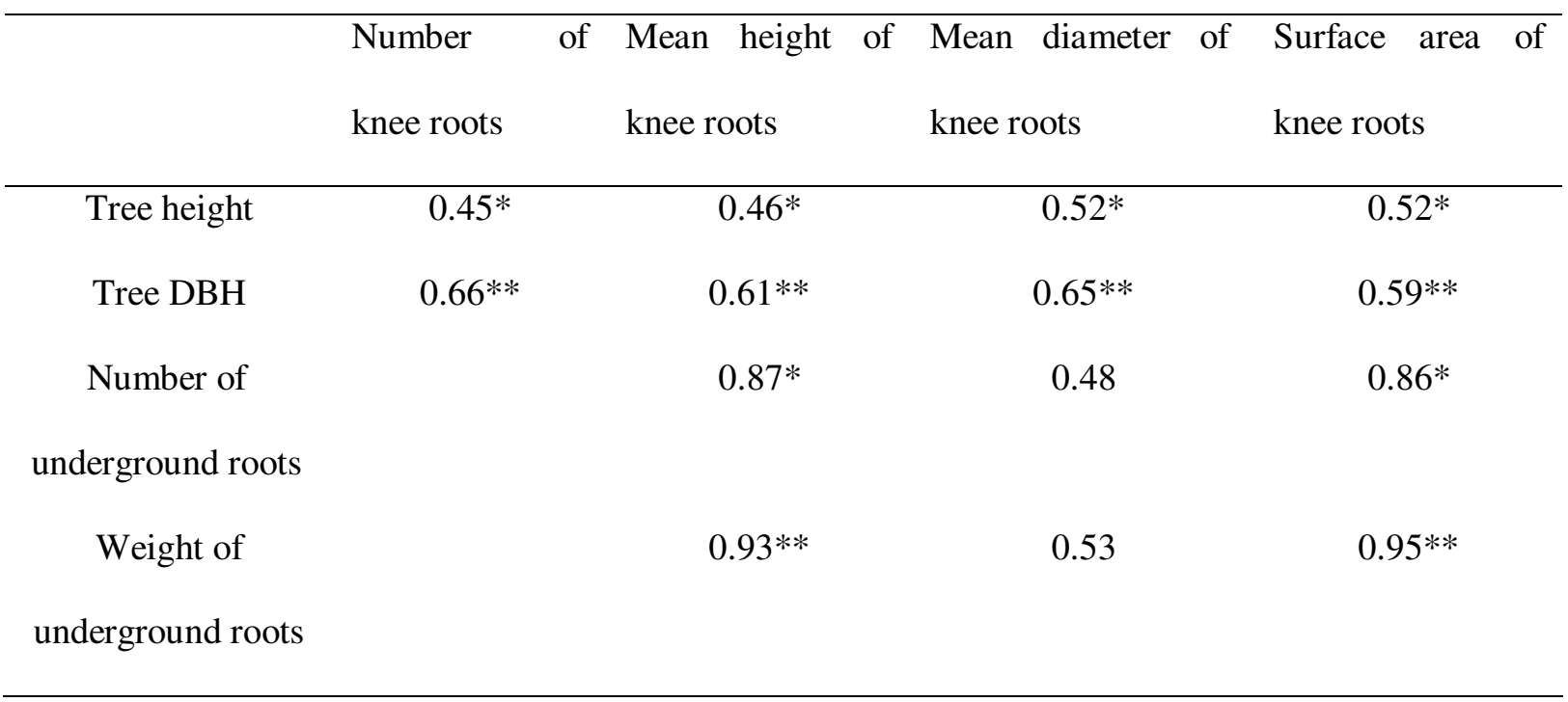

$505 \mathrm{DBH}$, diameter at breast height. $* \mathrm{P}=0.05$ significance; $* * \mathrm{P}=0.01$ significance.

506

507

508 

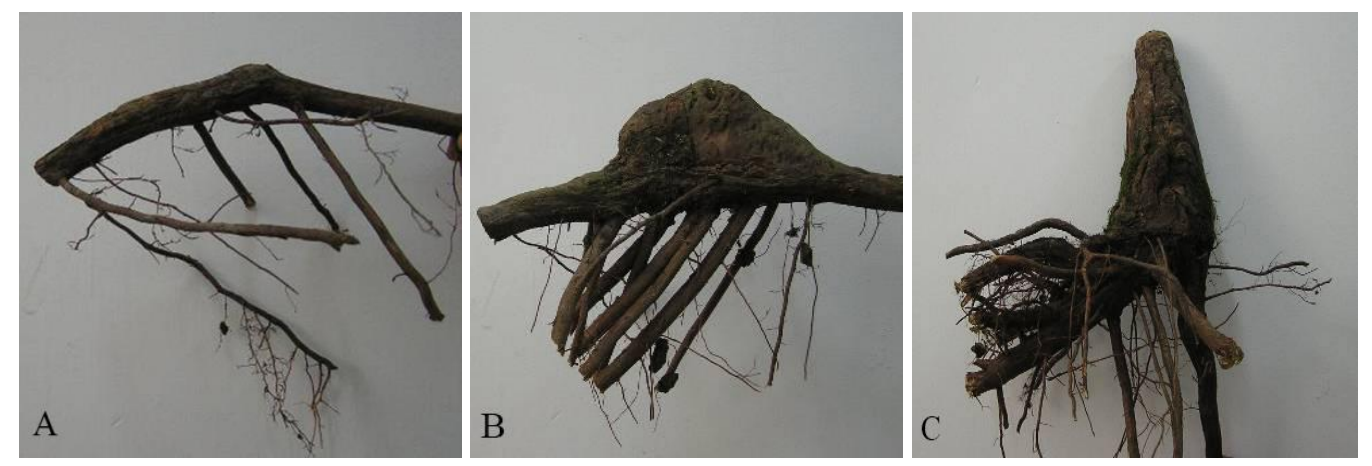

511 Fig. 1 Photographs of knee roots of young-aged stage (A), middle-aged stage (B), and old-aged stage 512 (C). 

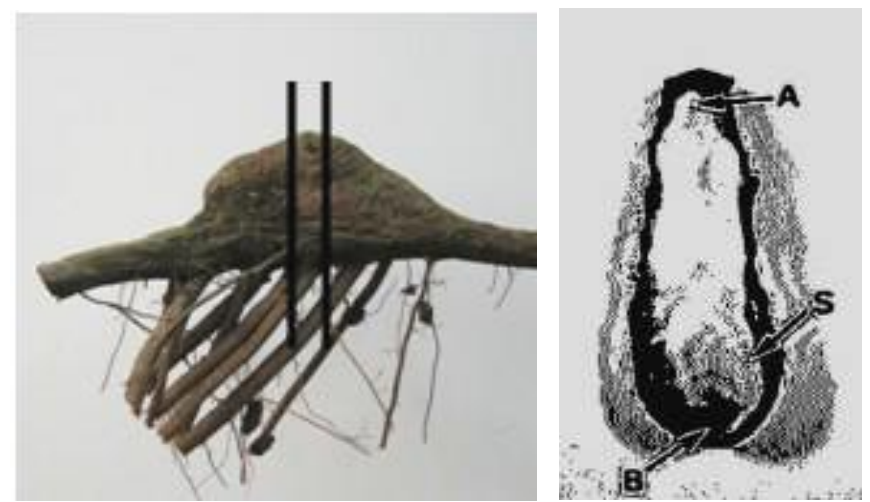

516 Fig. 2 Photographs of a root segment with a knee root (left) and transverse section of a knee root

517 (right).

518 Vertical bars indicate the portion with the transverse section of the knee root. Letters indicate positions

519 of samples for microscopic observations. A, apex.

520 


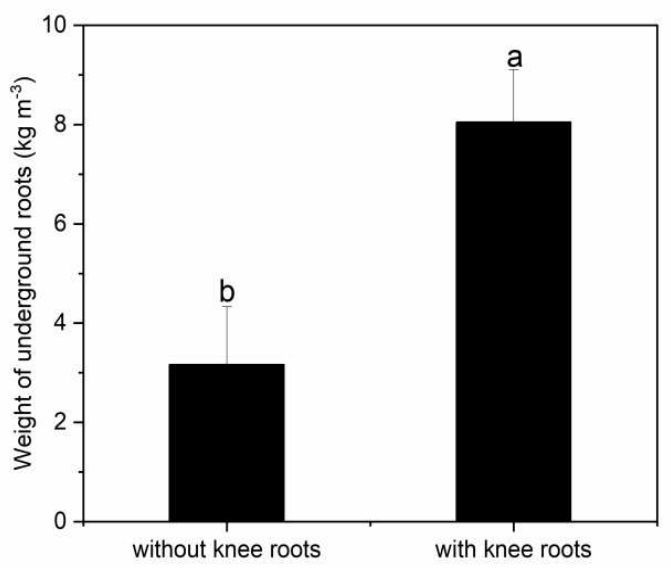

522

523 Fig. 3 Weight of underground roots with or without knee roots

524 Values followed by the same letter(s) are not significantly different at $P<0.05$, according to Duncan's

525 multiple range tests. Error bars are standard error of the mean; $\mathrm{n}=3$.

526 

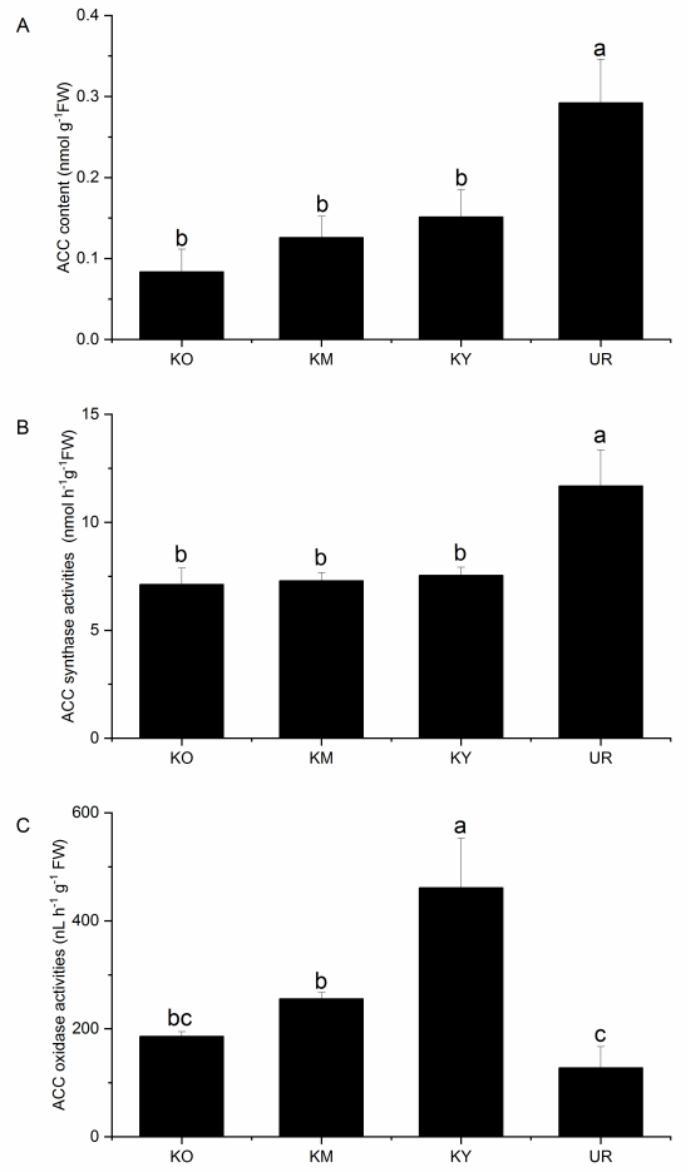

530 Fig. 4 ACC content and ACC synthase and ACC oxidase activities in different roots of Taxodium

531 ascendens $(\mathrm{KO}, \mathrm{KM}$, and $\mathrm{KY}$ refer to the knee roots at different development stages: old-aged stage,

532 middle-aged stage, and young-aged stage, respectively. UR means underground roots.). Values

533 followed by the same letter(s) are not significantly different at $\mathrm{P}<0.05$, according to Duncan's

534 multiple range tests. Error bars are standard error of the mean; $n=3$. 

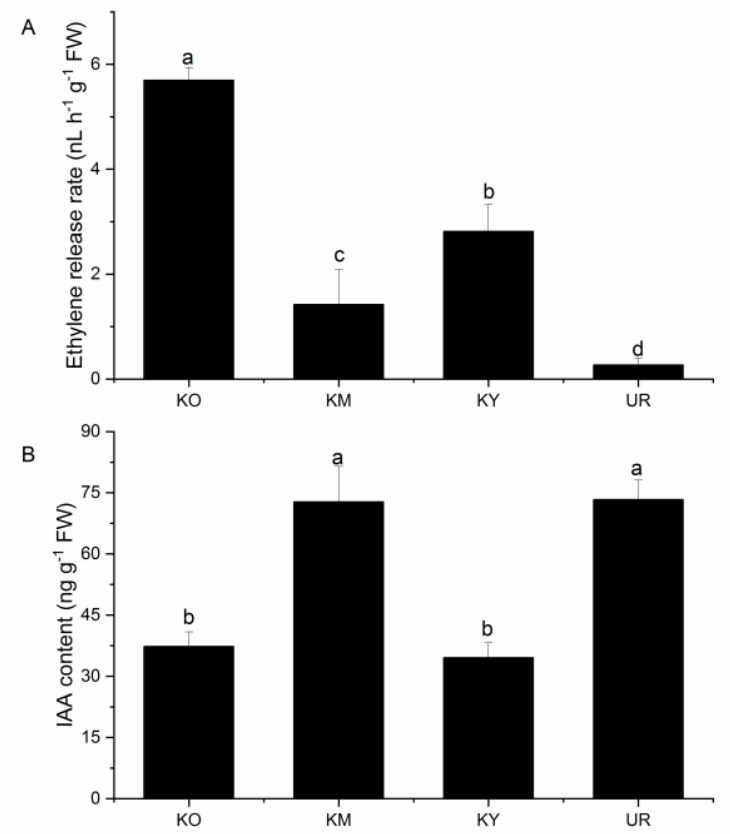

537

538 Fig. 5 Ethylene release rates from different root types of Taxodium ascendens

539 
540

541

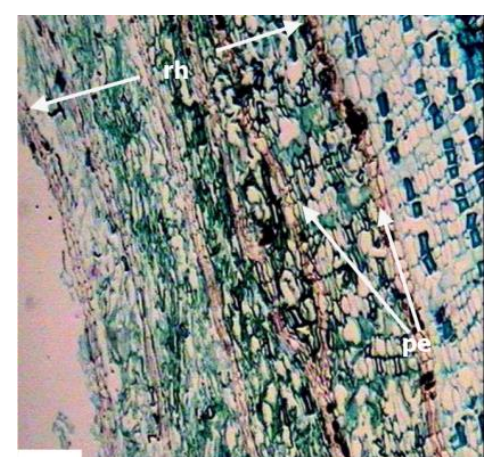

1

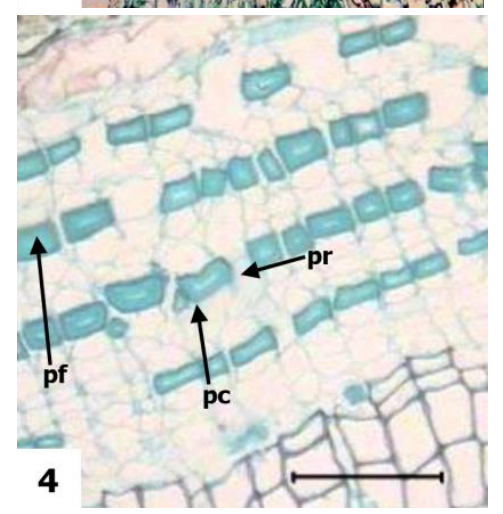

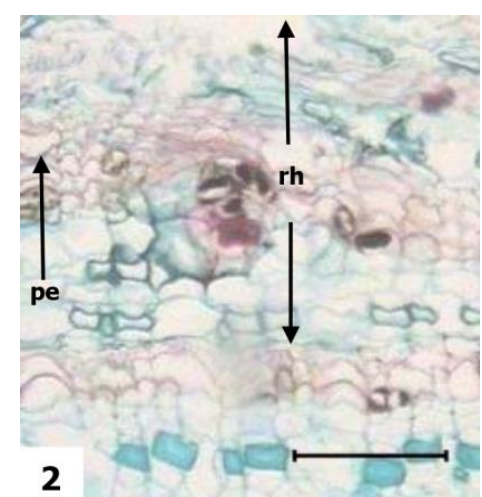

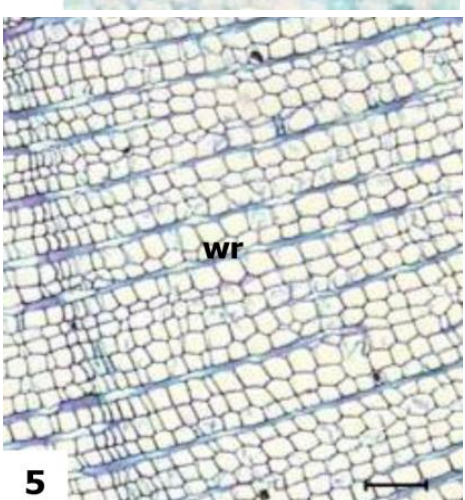

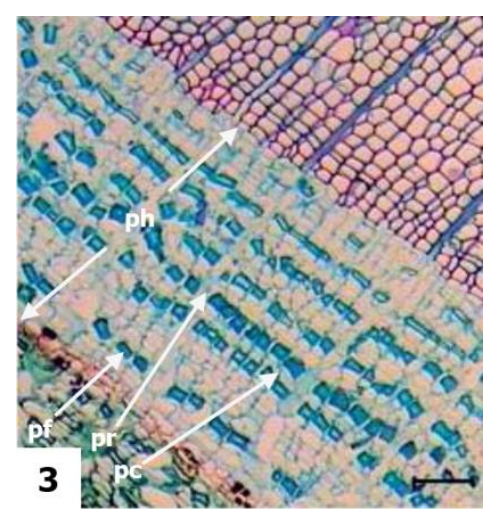

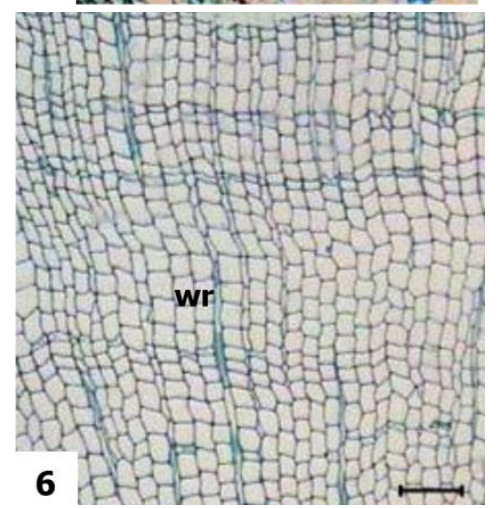

542

543 Fig. 6 Transverse anatomical structure of knee roots and underground roots

544 Horizontal line $=100 \mu \mathrm{m}$. 1, Rhytidome at the apex of the knee roots (middle stage); 2, rhytidome of

545 mid-sized underground roots; 3, phloem at the apex of the knee roots (middle stage); 4, phloem of

546 mid-sized underground roots; 5 , xylem at the apex of the knee roots (middle stage); 6 , xylem of mid-

547 sized underground roots; rh: rhytidome; pe: periderm; ph: phloem; pr: phloem ray; pf: phloem fiber;

548 pc: phloem parenchyma cell; wr: wood ray. 
550

551

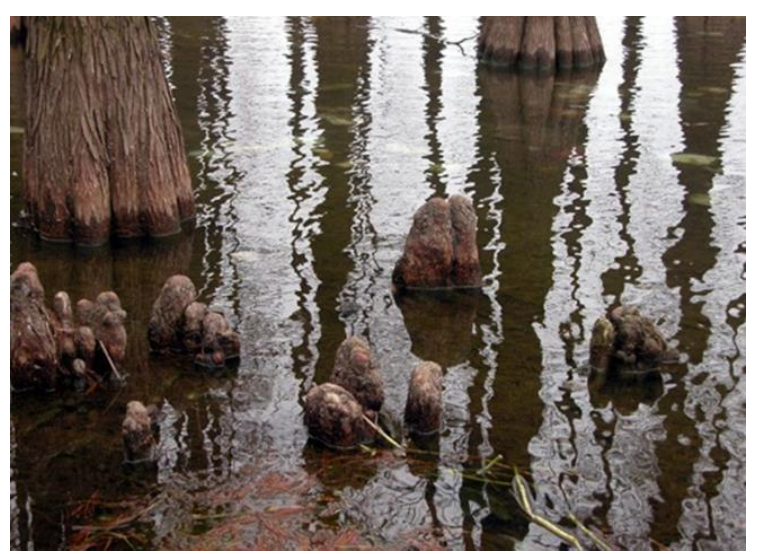

552 Fig. 7 Knee roots of Taxodium ascendens in the wetland

553 


\section{Figures}
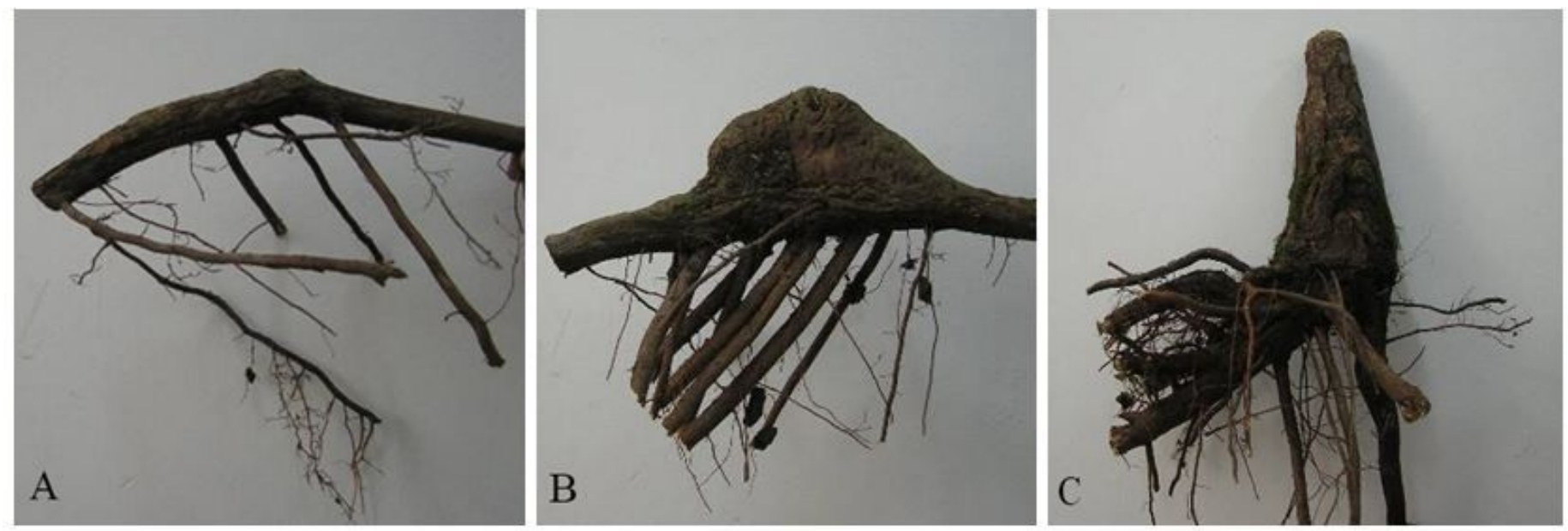

\section{Figure 1}

Photographs of knee roots of young-aged stage (A), middle-aged stage (B), and old-aged stage (C).
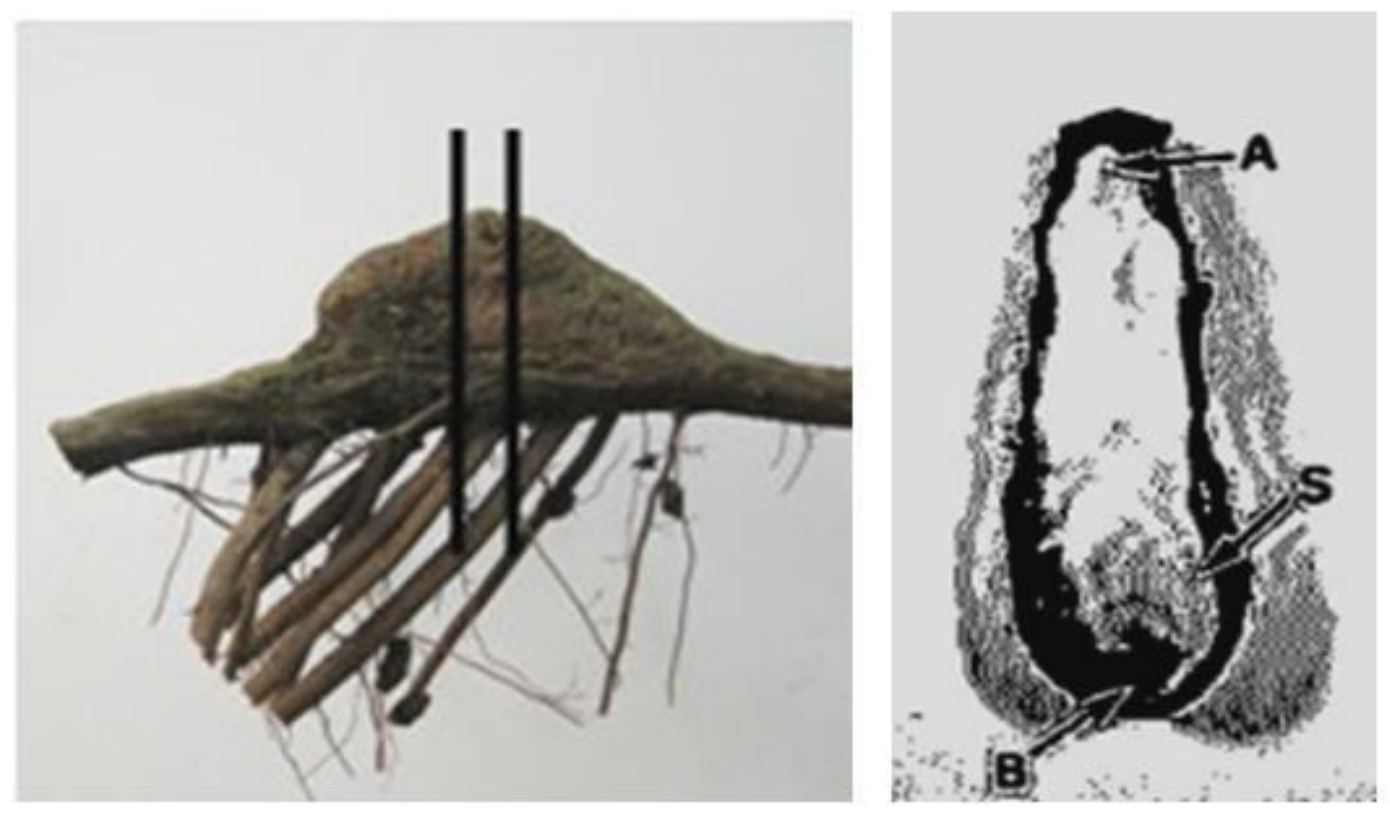

Figure 2

Photographs of a root segment with a knee root (left) and transverse section of a knee root (right). Vertical bars indicate the portion with the transverse section of the knee root. Letters indicate positions of samples for microscopic observations. A, apex. 


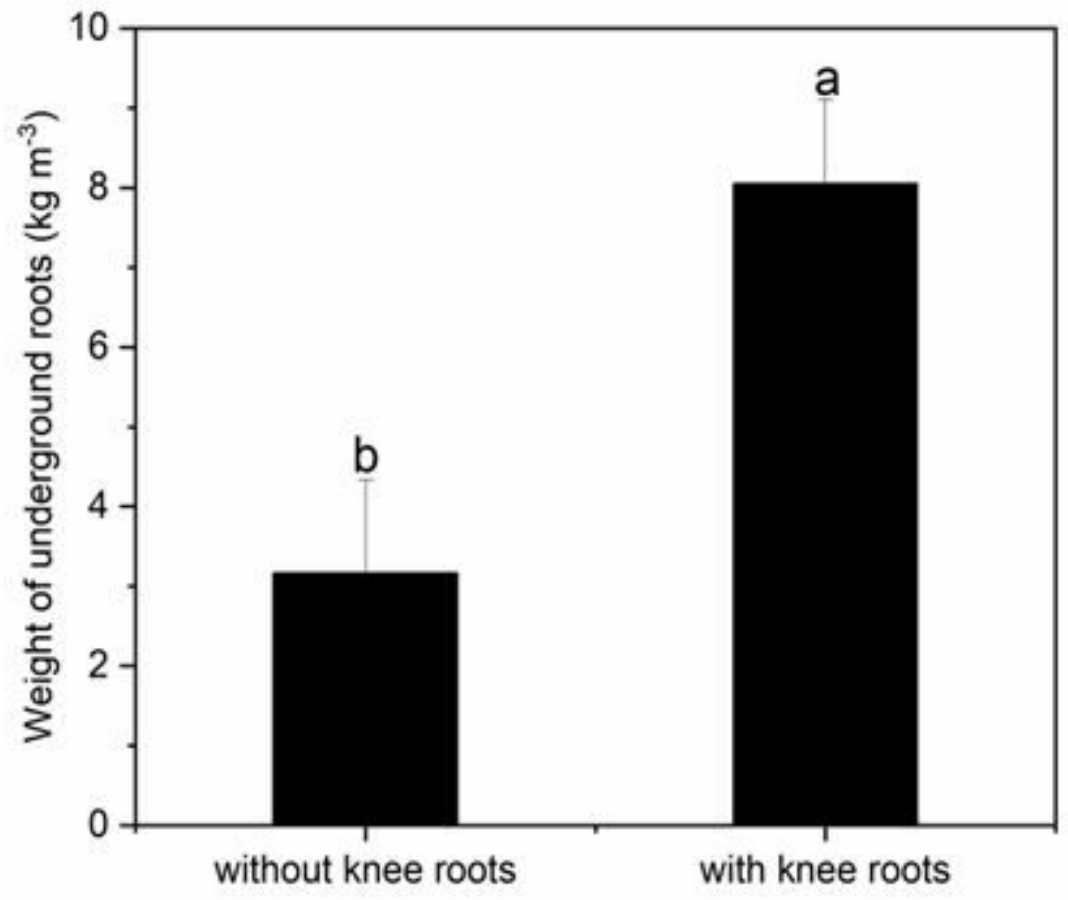

Figure 3

Weight of underground roots with or without knee roots Values followed by the same letter(s) are not significantly different at $\mathrm{P}<0.05$, according to Duncan's multiple range tests. Error bars are standard error of the mean; $n=3$. 
A

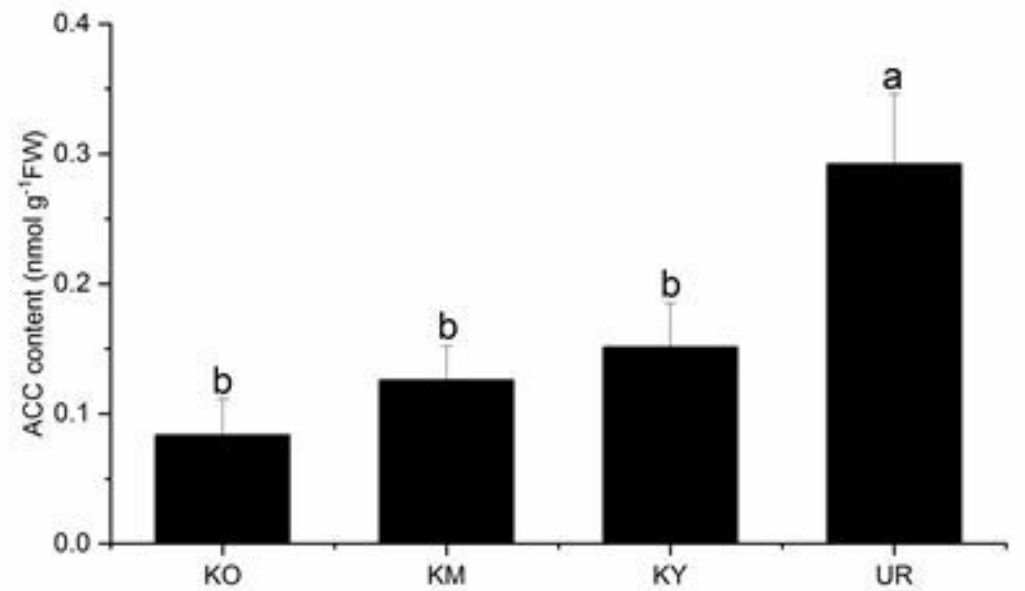

B

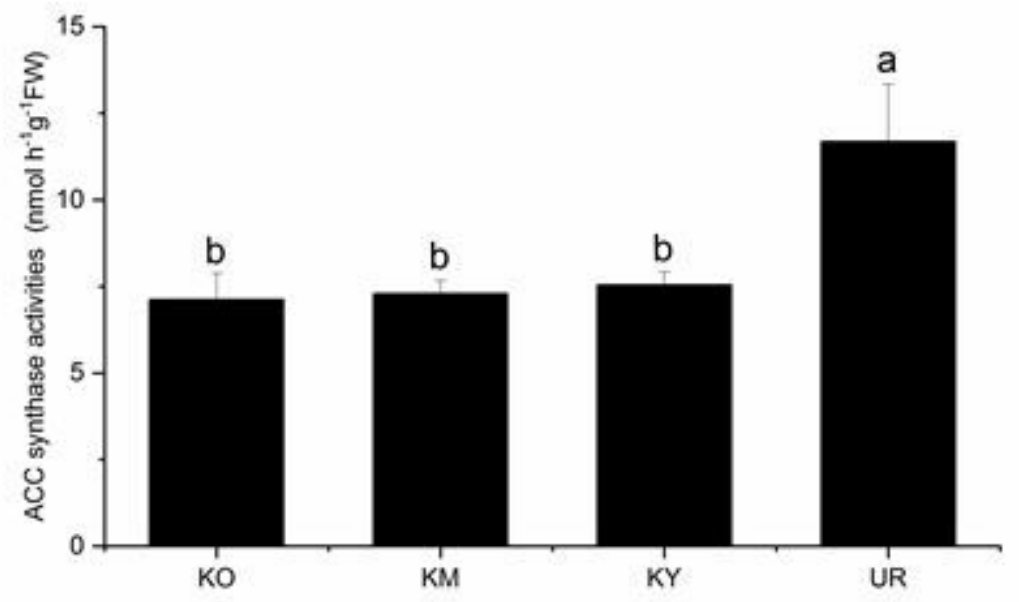

C

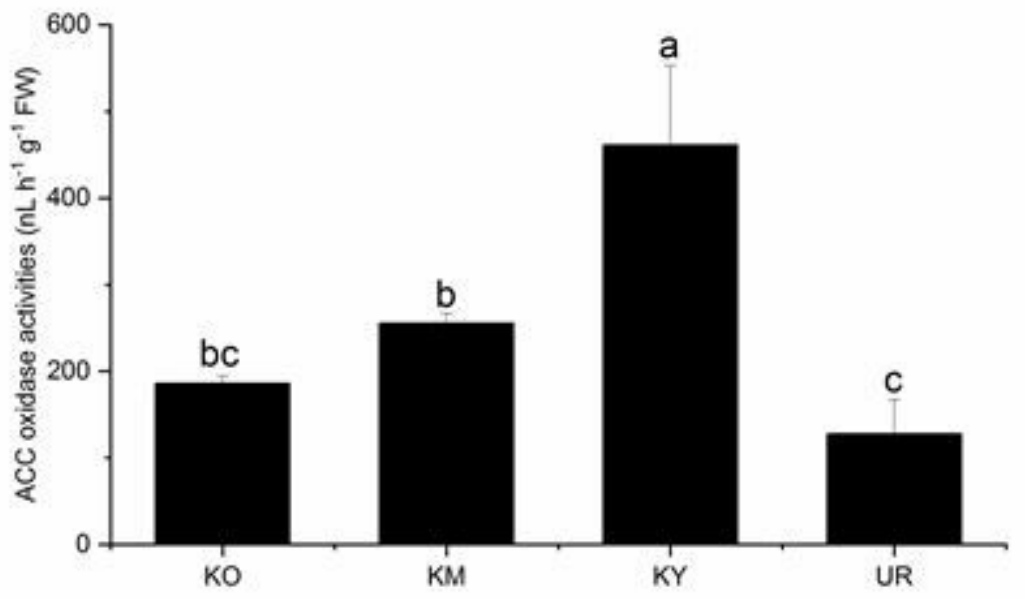

Figure 4

ACC content and ACC synthase and ACC oxidase activities in different roots of Taxodium ascendens (KO, $\mathrm{KM}$, and $\mathrm{KY}$ refer to the knee roots at different development stages: old-aged stage, middle-aged stage, and young-aged stage, respectively. UR means underground roots.). Values followed by the same letter(s) are not significantly different at $\mathrm{P}<0.05$, according to Duncan's multiple range tests. Error bars are standard error of the mean; $n=3$. 

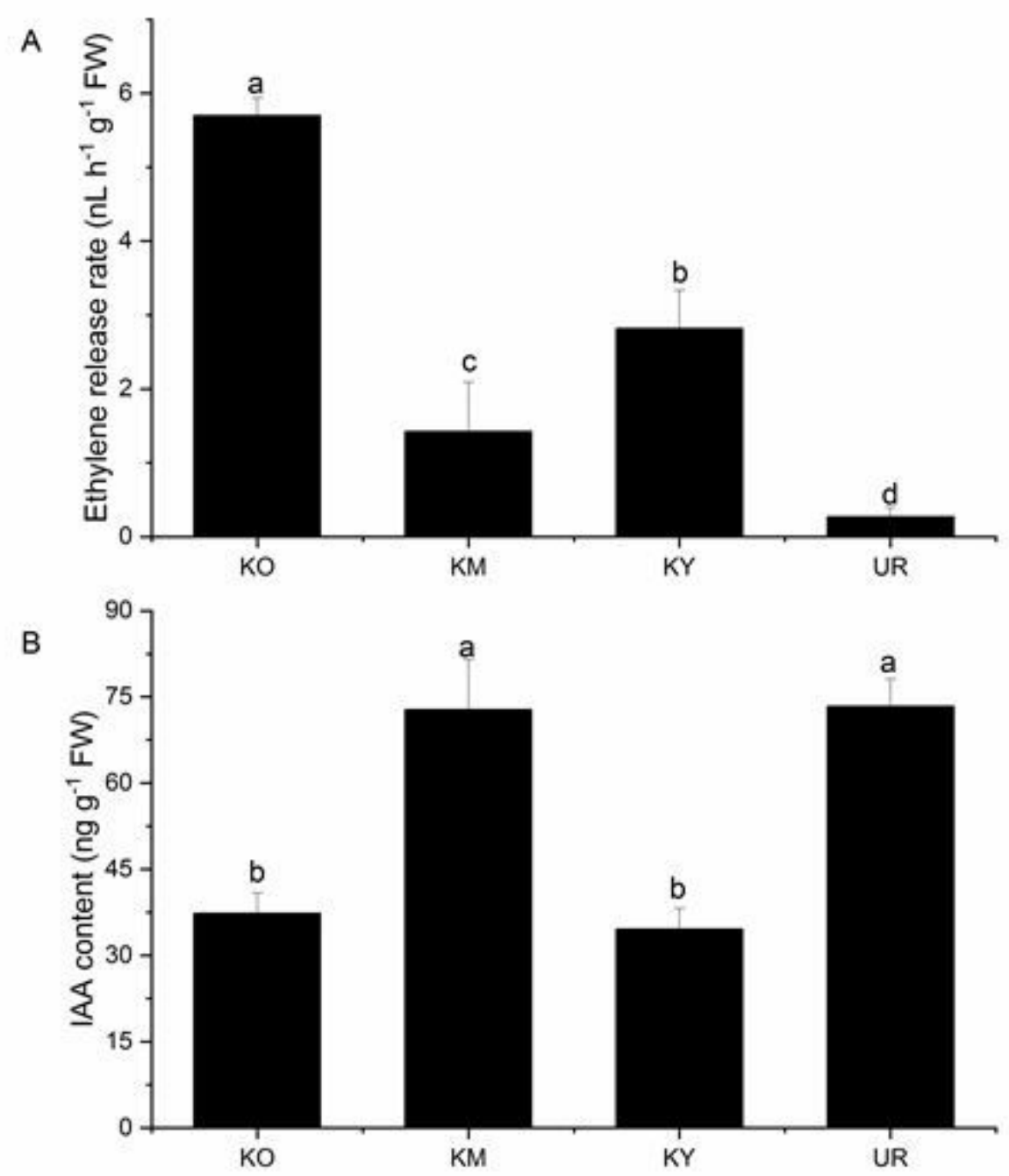

Figure 5

Ethylene release rates from different root types of Taxodium ascendens 


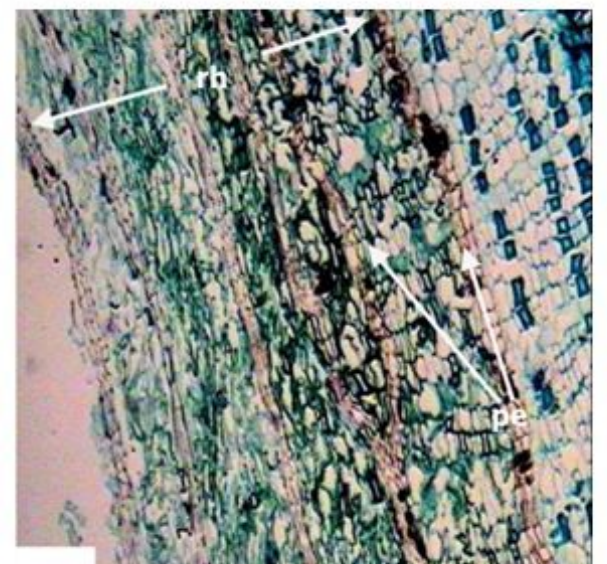

1

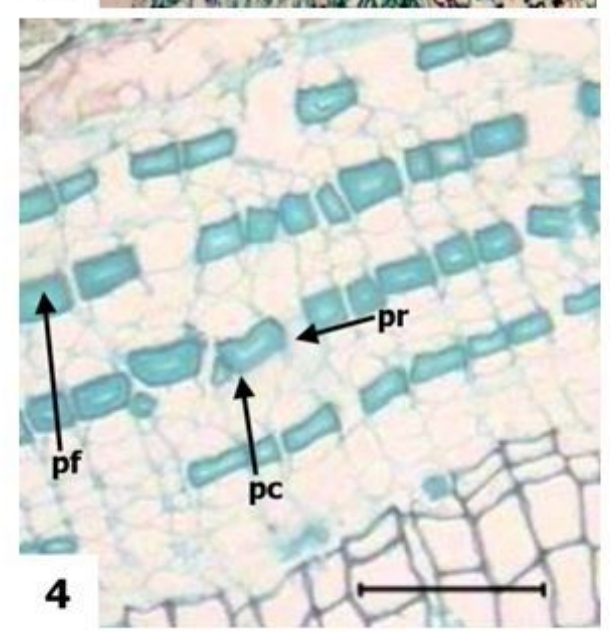

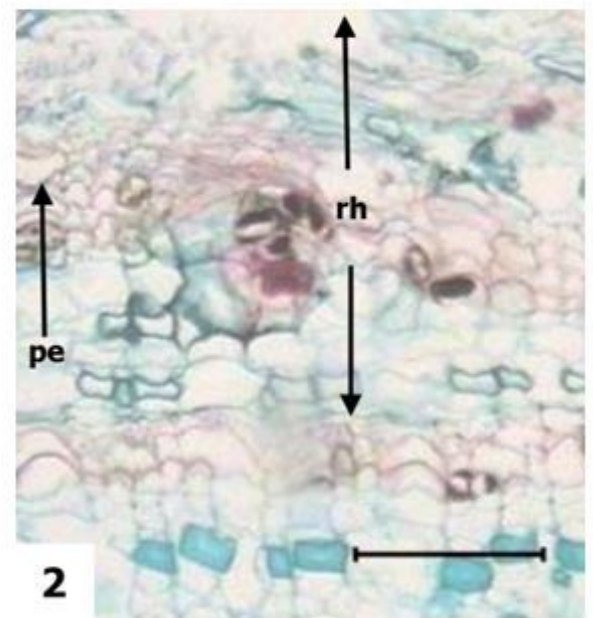

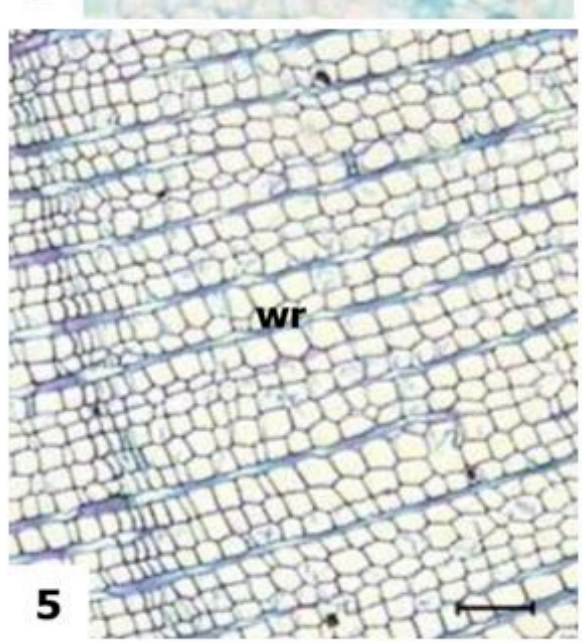

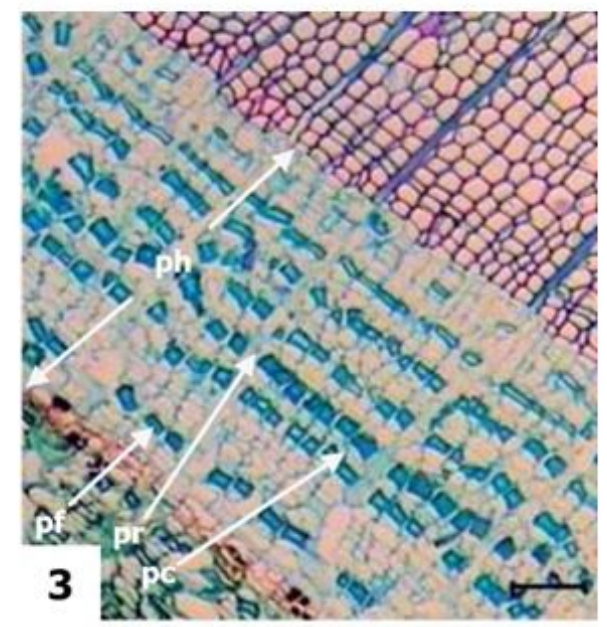

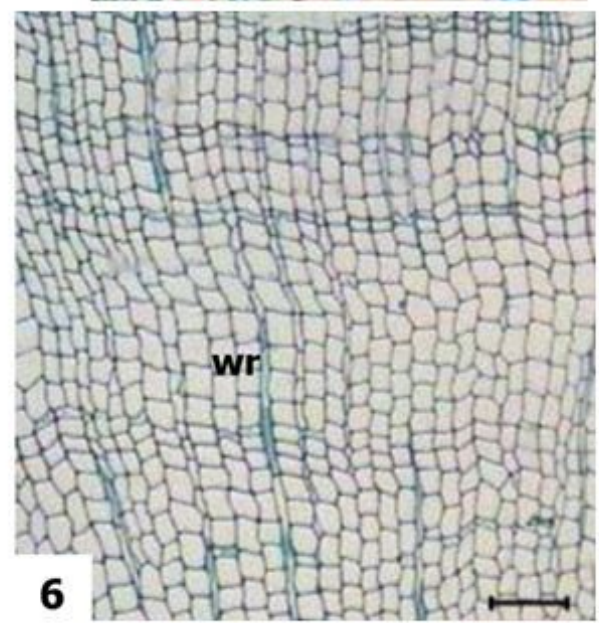

Figure 6

Transverse anatomical structure of knee roots and underground roots Horizontal line $=100 \mu \mathrm{m} .1$, Rhytidome at the apex of the knee roots (middle stage); 2, rhytidome of mid-sized underground roots; 3 , phloem at the apex of the knee roots (middle stage); 4 , phloem of mid-sized underground roots; 5 , xylem at the apex of the knee roots (middle stage); 6 , xylem of mid-sized underground roots; rh: rhytidome; pe: periderm; ph: phloem; pr: phloem ray; pf: phloem fiber; pc: phloem parenchyma cell; wr: wood ray. 


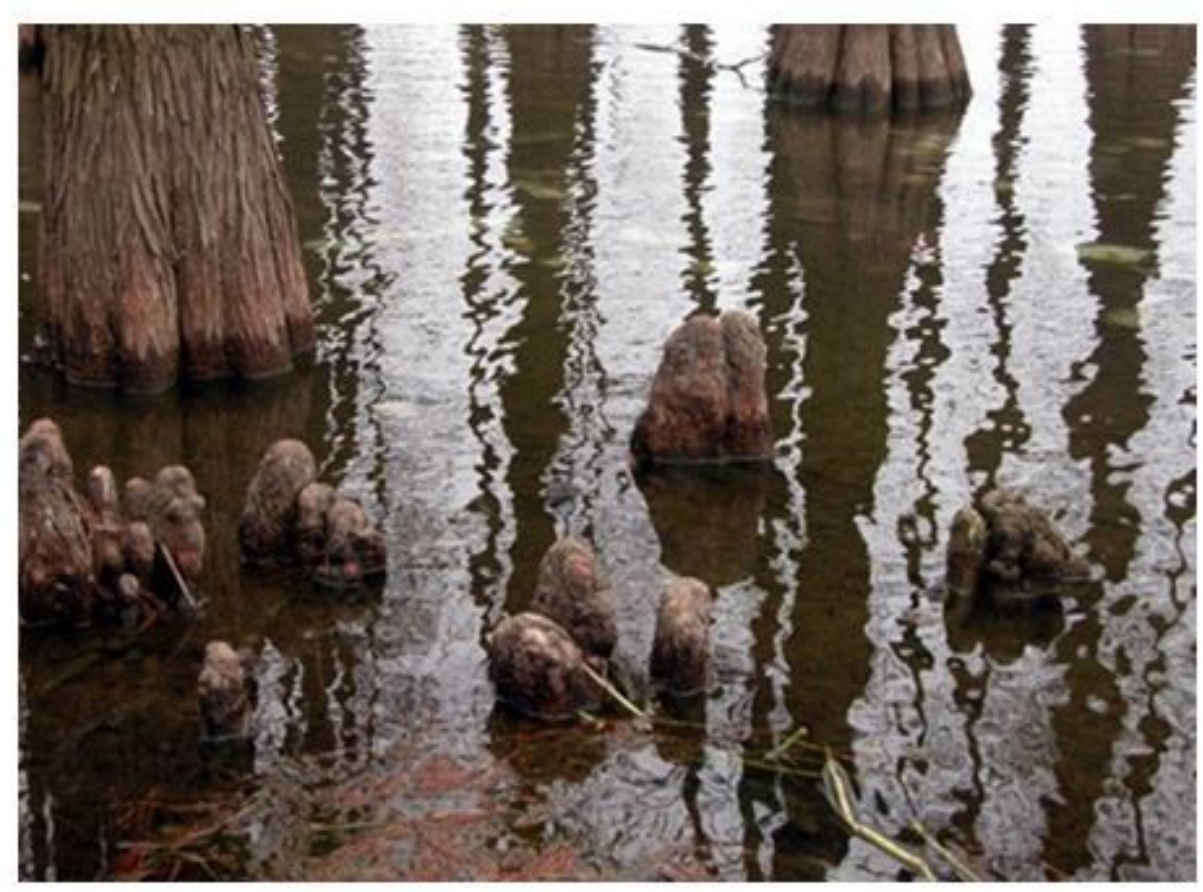

Figure 7

Knee roots of Taxodium ascendens in the wetland 